\title{
ANALYSIS OF CRITICAL THINKING SKILLS BY HOMESCHOOLING'S STUDENTS IN SOLVING MATHEMATICAL PROBLEM
}

\author{
Fitriatus Sholihah, Siti Inganah, Moh. Mahfud Effendi \\ Department of Mathematics Education, Faculty of Teacher Training and Education \\ University of Muhammadiyah Malang \\ fitriatussholihah84@gmail.com
}

\begin{abstract}
This study aims to describe the critical thinking skills of homeschooling students in solving mathematical problems. The type of this research is descriptive research with qualitative approach. Subjects in this study were six students homeschooling is equivalent to junior high school students class IX. Data were obtained through tests and interviews. Test are identified and described in accordance with the achievement of students towards critical thinking indicators used in this research that clarification, assessment, strategy/ tactics, and inference. The results of the interviews are used to further strengthen the data on homeschooling students' critical thinking skills. The results showed that one homeschooling student is in the category of less critical, four students are on quite critical category and only one student in a critical category. This suggests that homeschooling students' critical thinking skills are low. Low critical thinking skills are affected by limitations homeschooling student learning of mathematics is done, students 'mathematical ability and mathematical learning processes that do not yet geared to developing homeschooling students' critical thinking skills. So that based on the results of this study are advised to make the learning process of mathematics to develop homeschooling students' critical thinking skills.
\end{abstract}

Keywords: Critical thinking, Homeschooling

\section{INTRODUCTION}

Critical thinking is an ability that is very important for each individual, because almost all aspects of life require the ability to think critically. Critical thinking means thinking sensible and reflective, remains open to different perspectives and does not believe easily any information without a further legible source, and it requires a great effort to examine any belief or knowledge assumptive based on supporting evidence and conclusions advanced the resulting (Desmita, 2014; Ennis, 1993; Fisher, 2009). Someone who has a high ability to think critically,will be more careful, meticulous and cautious tosolve the problems. Critical thinking capability will not be progressing if at school do not develop basic skills such as reading and mathematics skills (Desmita, 2014). Santrock 
(2008) also revealed that if the solid foundation for the fundamental skills such as mathematics skills is not developed during childhood, critical thinking capabilities are not likely to mature in adolescence. It can be concluded that mathematics is a lesson that can be used to develop students critical thinking skills.

Learning mathematics can be acquired through education. The most common education and has many devotees are formal education, where the education will be implemented gradually from basic education to higher education. In formal education, students who have a different background, characteristics and learning styles put together in one class. Teachers cannot really understand and focus on each student, so the ability of students cannot be developed properly. In addition, the solid lesson hours in formal education makes students less able to develop its potential. This has caused many parents choose homeschooling for their children's education.

Homeschooling is a home-based education model, where parents fully responsible to educate and develop the character of the child (Hanaco, 2012). Parents do not hand over responsibility for the education of children to teachers and school system for granted, but is also responsible on their children's education process. Jamal (2012) also found through homeschooling, parents can keep an eye on, push, dig, explore, and develop the potential of children directly with the greatest earnestness, sincerity and hard work. Homeschooling has similarities with the school; they both aim to deliver the children on educational goals. The differences of homeschooling between schools are in the school system, the education of children delegated responsibility of parents to teachers and schools, while in homeschooling, responsibility for the education of children rests with the parents. In addition, the school system to fulfill the needs of children in general, while homeschooling adjusted according to the needs of the child and family circumstances (Sumardiono, 2007). Based on interviews with one of the mathematics teachers in homeschooling.

Primagama on November 24, 2016 students can actively follow the process of learning mathematics, but students still have difficult in solving a problem. Moreover, the mathematics lesson in homeschooling of Primagama course is given only once a week and student-centered in mathematics learning. According to Lambertus (2009), a student- centered learning is potential for training critical thinking skills, 
because the students are given the autonomy for building their own knowledge, asking freely, accepting and rejecting the opinion, and drawing conclusions through teachers' guidance.

Critical thinking capability of students occurs through several stages. This research uses critical thinking indicators according to the stages of Perkins \& Murphy (2006), which consists of clarification, assessment, strategy/ tactics, and inference. Clarification is the student's ability to identify problems and formulate the problem issues. Assessment is the students' ability to connect what is known on the matter and is capable of selecting the appropriate stages. Strategy/ tactics are the students' ability to solve problems, and the last indicator that the inference is the students' ability to draw conclusions clearly and logically from the results of the investigation.

Associated with the critical thinking capability of students in mathematical problem solving, research from Anistawati (2016) showed that from 22 students of class VIII at SMP Muhammadiyah 8 Batu, there are 17 students with a level of critical thinking 1 (less critical), 5 students with a level of critical thinking 2 (quite critical), and there are only two students who were at the level of critical thinking 3 (critical). Based on these results, it can be said that the level of junior high school students' critical thinking in solving mathematical problems is still relatively low. Research from Fithriyah (2016) also revealed that of the 26 students of class IX-D in SMPN 17 Malang, the critical thinking ability of students is still relatively low.

The results of these two studies indicate that the critical thinking ability of junior high school students is low, whereas mathematics lesson in junior high school is taught more than once in a week and the process of research is always accompanied by teachers, while mathematics lesson in homeschooling is only given once a week and the study time more flexible. It is possible to make the level of critical thinking capability of homeschooling's students is also low, but it cannot be concluded without the existence of an investigation. Therefore, the goal of this research is to describe the critical thinking capability of homeschooling's students in solving mathematical problems. 


\section{METHOD RESEARCH}

This study aims on describing the critical thinking skills of homeschooling's students in mathematical problem solving, so the type of study is a descriptive research, while the approach of the study is a qualitative approach. Subjects in this study were six students homeschooling Primagama who have the same ability and equal to the junior high school students class IX.

Data collection techniques used in this research are test and interview. Test is used to determine the ability of homeschooling's students' critical thinking in solving mathematical problems. Test that used in this research is a written test with a test description consists of 2 questions with the material on volume with curved side. Interview was used as a follow-up of tests to learn more about homeschooling's students' critical thinking. Therefore, the points in the question adjusted with the results of tests which have been done homeschooling students.

The critical thinking ability of homeschooling's students in this research is categorized into five categories: very critical, critical, quite critical, less critical and noncritical. The levels of these categories are based on the achievement of indicators of homeschooling's students' critical thinking in solving mathematical problems. If the homeschooling's students fulfill more indicators, it's mean that the critical thinking capabilityof the students is higher.

\section{RESULTS AND DISCUSSION}

The critical thinking skills of homeschooling's students in solving mathematical problem was obtained from test and interviews. Test and interviews were conducted with six students homeschooling consisting of MCH, VN, NTH, NL, NK and STP. The results of the tests and interviews were analyzed based on indicators of critical thinking which consists of clarification, assessment, strategy/ tactics, and inference.

The results of the analysis have been done on the critical thinking skills of homeschooling's students in mathematical problem solving in six homeschooling's students whic is equivalent to junior high school students class IX shows that there is only one student, $\mathrm{MCH}$, which is categorized as critical, where $\mathrm{MCH}$ is able to identify and 
formulate problems correctly and completely, connect the existing matter, and choose the appropriate stage, solve the problem with one settlement and make conclusion with the correct answer. Four homeschooling's students are VN, NTH, NL and NK are in the quite critical category, where students are able to identify and formulate problems correctly and completely, connect what is known on the matter and choose the stages that suit, but less able to solve the problem because wrong of the calculations, and draw conclusions with the wrong answer. One student that STP is in the less critical category, where student is less able to identify and formulate problems, linking what is known in the problem and the steps being taken less appropriate, less able to solve the problem because of wrong of the equations and less able to draw conclusions.

The results of data analysis showed none of homeschooling's students classified as very critical because there are no students who solve problems with a variety of alternative settlement. The average student is in the quite critical category, so the ability of homeschooling's students' critical thinking is still relatively low. The results are consistent with studies of Fithriyah (2016) which states that the average critical thinking ability of students is still relatively low. Although research conducted not in homeschooling but the results obtained are the same. This is because, both students' formal education and homeschooling, the average is not able to resolve the problem properly and is unable to meet all of the indicators used critical thinking.

The homeschooling's students'critical thinking skills are still relatively low causing homeschooling's students are less able to solve the problem properly. The average homeschooling's students have been able to understand the problem and devise a plan, but homeschooling's students less able to carry out the plan that produced incorrect answers. This is in line with research from Kusmanto (2014), which revealed that the ability to think critically affect the student's ability in solving mathematical problems.

Learning mathematics in homeschooling have a very limited time, which is given only once a week. This affects the student's ability in solving mathematical problems, because homeschooling's students have less time to try the various mathematical problems. In contrast to the formal education, the learning of mathematics is given more than once a week. Students will be more trying to solve various mathematical problems. Therefore homeschooling's students have limited time in the learning of mathematics, the 
homeschooling's students' critical thinking skills is still relatively low. So when learning of mathematics should be added that homeschooling's students' critical thinking skills can be improved.

Another factor affecting homeschooling's students' critical thinking skills is a learning process of mathematics. The process of learning mathematics between one homeschooling's student and other students are not same. This is because the process of mathematics done in homeschooling adjusted to the conditions, the capabilities and characteristics of students (Rohmawatiningsih, 2013). Therefore, students who have a higher capacity will more quickly understand the material which is presented by the teacher, so the homeschooling's teacher usually does not provide a formula, but the teachers guide students to discover the formula itself. While students who have a low ability to be slower in understanding the material, so that the teachers directly to give the formula to homeschooling's students so that all matter can be resolved. This causes homeschooling's students who have a low ability are less able to improve critical thinking skills because it used to derive formulas and memorize it.

The process of learning mathematics can not be separated from approach learning. Contextual approach is an approach that can be done on the study of mathematics and the approach can improve students' critical thinking skills (Suwanjal, 2016). However, mathematics lesson in homeschooling rarely using a contextual approach, so the ability to think critically is also not easy to improve. This suggests that the factors that can improve critical thinking skills are less implemented in homeschooling so it cause the average of homeschooling's students critical thinking skills still low.

\section{CONCLUSION}

Critical thinking skill is a skill that is needed in solving mathematical problems. The results of research on homeschooling's students' critical thinking skills in mathematical problem solving can be concluded that only one homeschooling's students who is in critical categories, four students are on quite critical categories and one students is in the category of less critical. Homeschooling's students have been able to identify, formulate the problem issues properly and able to connect what is known on the matter to 
select the appropriate stage. However, the average of homeschooling's students are less able to solve the problems properly so that the students write a conclusion with the wrong answer. The average of homeschooling's students who are less able to solve the problems properly causing homeschooling's students' critical thinking skills are low. The low of homeschooling's students critical thinking skills are affected by the limited time of learning mathematics, mathematical ability of students is not high enough, and the learning process of mathematics which do not yet geared to developing homeschooling's students' critical thinking skills.

\section{REFERENCES}

Anistawati, R. D. 2016. Analysis of the Critical Thinking Skills of Students in Solving Mathematical Problems Based on Polya Steps. Thesis not published. Malang: Faculty of Teacher Training and Education University Muhammadiyah of Malang.

Desmita. 2014. Psychology Development of Learners. Bandung: PT Remaja Rosda Karya.

Ennis, R. H. 1993. Theory Into Practice: Critical Thinking Assesment. College of Education: The Ohio State University.

Fisher, A. 2009. Introduction to Critical Thinking. Jakarta: Erlangga.

Fithriyah, I. 2016. Analysis of Critical Thinking Skills of Class IX-D Students SMPN 17 Malang. Paper presented at National Conference on Research on Mathematics and Learning (KNPMP I), Muhammadiyah University of Surakarta, March 12, 2016.

Hanaco, I. 2012. I Love Homeschooling. Jakarta: Gramedia.

Jamal. 2012. Smart Book Homeschooling. Jogjakarta: FlashBooks.

Kusmanto, H. 2014. The Influence Of Critical Thinking Of Students' Ability In Solving Mathematical Problems. EduMa, 3(1), 92-106.

Lambertus. 2009. The Importance of Practicing Critical Thinking Skills in Mathematics Learning in Primary Schools. Education Journal, 28(1), 136-142.

Regulation of the Minister of Education and Culture No. 21 of 2016 on Basic and Secondary Education Content Standards.

Perkins, C., \& Murphy, E. 2006. Identifying and measuring individual engagement in critical thinking in online discussions: An exploratory case study. Educational Technology \& Society, 9 (1), 298-307. 
Rohmawatiningsih. 2013. Implementation of Mathematics Learning Process Class VIII Homeschooling Kak Seto Semarang. Thesis not published. Semarang: Faculty of Tarbiyah and Teacher Training of Walisongo State Islamic Institute

Santrock, J. W. 2008. Educational Psychology. Jakarta: Salemba Humanika.

Sumardiono. 2007. Homeschooling A Leap for Better Learning The Leap How To Learn. Jakarta: PT Elex Media Komputindo.

Suwanjal, U. 2016. The Effect of Implementing Contextual Approaches to Mathematical Critical Thinking Skills Junior High School Students. Mathematics Education Journal, 5(1), 61-67. 